Violence in the City of Women 
This page intentionally left blank 


\section{Violence in the City of Women}

POLICE AND BATTERERS IN BAHIA, BRAZIL

Sarah J. Hautzinger

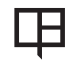

UNIVERSITY OF CALIFORNIA PRESS

BERKELEY LOS ANGELES LONDON 
University of California Press, one of the most distinguished university presses in the United States, enriches lives around the world by advancing scholarship in the humanities, social sciences, and natural sciences. Its activities are supported by the UC Press Foundation and by philanthropic contributions from individuals and institutions. For more information, visit www.ucpress.edu.

University of California Press

Berkeley and Los Angeles, California

University of California Press, Ltd.

London, England

(C) 2007 by The Regents of the University of California

Library of Congress Cataloging-in-Publication Data

Hautzinger, Sarah J., 1963-.

Violence in the city of women : police and batterers in Bahia, Brazil / Sarah J. Hautzinger.

p. $\mathrm{cm}$.

Includes bibliographical references and index.

ISBN-I3: 978-0-520-25276-9 (cloth : alk. paper)

ISBN-I3: 978-0-520-25277-6 (pbk. : alk. paper)

I. Women-Brazil-Bahia (State) 2. Policewomen-

Brazil-Bahia (State) 3. Family violence-Brazil-Bahia (State) 4. Masculinity-Brazil-Bahia (State) 5. Sex role-Brazil-Bahia (State) I. Title.

$$
\begin{aligned}
& \text { HQI544.B33H38 } 2007 \\
& \text { 364.I5'553098I42-dc22 }
\end{aligned}
$$

2006036211

Manufactured in the United States of America

$$
\begin{aligned}
& \begin{array}{llllllllll}
\text { I6 } & \text { I5 } & \text { I4 } & \text { I3 } & \text { I2 } & \text { II } & \text { IO } & 09 & 08 & 07
\end{array} \\
& \begin{array}{llllllllll}
\text { IO } & 9 & 8 & 7 & 6 & 5 & 4 & 3 & 2 & \text { I }
\end{array}
\end{aligned}
$$

This book is printed on New Leaf EcoBook 50, a I00\% recycled fiber of which $50 \%$ is de-inked post-consumer waste, processed chlorine-free. EcoBook 50 is acid-free and meets the minimum requirements of ANSI/ASTM D5634-OI (Permanence of Paper). 
In memory of my mother, Sue O'Brien 
This page intentionally left blank 